\title{
Pemberdayaan Perempuan sebagai Vulnerable Group dalam Penyebaran HIV/AIDS di Kelurahan Bastiong Kota Ternate
}

\author{
Muliana \\ Jurusan Keperawatan, Poltekkes Kemenkes Ternate \\ Corresponding Author. Email: muliana.ana64@yahoo.com
}

\begin{abstract}
The aim of implementing this community service is to increase the knowledge of housewives about preventing HIV/AIDS transmission with ABCD education in Bastiong Karance Village, Ternate City. The method used in the implementation of this activity is women's empowerment in the form of socialization and providing information starting from planning which includes identifying needs, identifying existing potentials and weaknesses, determining ways out of the activities to be carried out, and organizing, implementing, monitoring evaluation and final report preparation. Participants in community service activities are 35 housewives. The results of the community service activities carried out were an increase in the knowledge of housewives in an effort to prevent HIV/AIDS transmission in the Bastiong Karance Village, Ternate City.
\end{abstract}

Abstrak: Tujuan dari pelaksanaan pengabdian kepada masyarakat ini adalah meningkatkan pengetahuan ibu rumah tangga tentang pencegahan penularan HIV/AIDS dengan edukasi ABCD di Kelurahan Bastiong Karance Kota Ternate. Metode yang digunakan dalam pelaksanaan kegiatan ini adalah pemberdayaan dalam bentuk sosialisasi dan pemberian informasi yang dimulai dari perencanaan yang meliputi identifikasi kebutuhan, identifikasi potensi dan kelemahan yang ada, menentukan jalan keluar dari kegiatan yang akan dilakukan, dan membuat pengorganisasian, pelaksanaan, monitoring evaluasi dan terakhir penyusunan laporan. Peserta kegiatan pengabdian kepada masyarakat adalah ibu rumah tangga sejumlah 35 orang. Hasil dari kegiatan ini yaitu adanya peningkatan pengetahuan dalam upaya pencegahan penularan HIV/AIDS di Kelurahan Bastiong Karance Kota Ternate. Hasil dari kegiatan pengabdian kepada masyarakat yang dilakukan yaitu adanya peningkatan pengetahuan ibu rumah tangga dalam upaya pencegahan penularan HIV/AIDS di Kelurahan Bastiong Karance Kota Ternate.

\section{Article History:}

Received: 10-09-2021

Reviewed: 27-09-2021

Accepted: 11-10-2021

Published: 13-11-2021

Key Words:

Empowerment,

Vulnerable Group,

AIDS, ABCD

Education.

Sejarah Artikel:

Diterima: 10-09-2021

Direview: 27-09-2021

Disetujui: 11-10-2021

Diterbitkan: 13-11-2021

\section{Kata Kunci:}

Pemberdayaan,

Vulnerable Group, AIDS,

Edukasi ABCD.

How to Cite: Muliana, M. (2021). Pemberdayaan Perempuan sebagai Vulnerable Group dalam Penyebaran HIV/AIDS di Kelurahan Bastiong Kota Ternate. Jurnal Pengabdian UNDIKMA, 2(2), 157-165. doi:https://doi.org/10.33394/jpu.v2i2.4124

https://doi.org/10.33394/jpu.v2i2.4124

This is an open-access article under the CC-BY-SA License.

\section{Pendahuluan}

Permasalahan Human Immuno Virus (HIV) dan Aquired Immunodefisiency Syndrome (AIDS) sampai saat ini masih merupakan masalah kesehatan dunia karena setiap tahun insidennya terus meningkat (Fitrianingsih, Dewi, \& Woferst, 2018). Acquired immunodeficiency syndrome (AIDS) merupakan hal yang perlu menjadi perhatian, kasus AIDS sangat tinggi, hampir semua penderita AIDS meninggal dalam waktu lima tahun sesudah menunjukkan gejala pertama (Eda, Widjanarko, \& Widagdo, 2012). Acquired Immunodeficiency Syndrome (AIDS) adalah sekumpulan gejala dan infeksi (sindrom) yang timbul karena rusaknya sistem kekebalan tubuh manusia akibat infeksi virus HIV atau infeksi virus-virus lain yang mirip yang menyerang spesies lainnya (SIV, FIV, dan lain-lain)(Santoso 
\& Akbar, 2018). Virusnya sendiri bernama Human Immunodeficiency Virus (HIV) yaitu virus yang memperlemah kekebalan pada tubuh manusia. HIV dan virus-virus sejenisnya umumnya ditularkan melalui kontak langsung antara lapisan kulit dalam (membran mukosa) atau aliran darah, dengan cairan tubuh yang mengandung HIV, seperti darah, air mani, cairan vagina, cairan preseminal, dan air susu ibu. Penularan dapat terjadi melalui hubungan intim (vaginal, anal, ataupun oral), transfusi darah, jarum suntik yang terkontaminasi, antara ibu dan bayi selama kehamilan, bersalin, atau menyusui, serta bentuk kontak lainnya dengan cairan-cairan tubuh tersebut (Dom, Kareem, Abidin, Kamaruzaman, \& Kajindran, 2009; Kaida et al., 2015; Samanta, 2010).

Acquired Immunodeficiency Syndrome atau Acquired Immune Deficiency Syndrome (AIDS) diperkiraan telah menginfeksi 38,6 juta orang di seluruh dunia(Zeth, Asdie, Mukti, \& Mansoden, 2010). Perkembangan AIDS di Indonesia sejak kasus pertama tahun 1987 hingga Maret 2019 berjumlah 115.601 kasus. Presentase Kasus HIV terhitung bulan Januari-Maret 2019 adalah sekitar 70,8 \% dan terbanyak pada kelompok umur 25-49 tahun. Jumlah penderita AIDS menurut pekerjaan/status terbanyak pada tenaga non profesional (karyawan) sebanyak 547 orang dan urutan kedua ditempati oleh Ibu rumah tangga sebanyak 213. Sepuluh Provinsi dengan AIDS Case Rate Tertinggi Sampai dengan Maret 2019 yaitu Papua (623.58 kasus), Papua Barat (176.32 kasus), Bali (175.84 kasus), Kalimantan Barat (93.59 kasus), DKI Jakarta (78.26 kasus), Kepulauan Riau (65.09 kasus), Sulawesi Utara(63.11), Kalimantan Utara (50.17 kasus), Maluku Utara (40.71 kasus) dan Jawa Timur (39.74 kasus). Berdasarkan data tersebut Maluku Utara menempati urutan ke 9 dalam kassus AIDS. Jumlah Kematian AIDS yang Dilaporkan Menurut Tahun, 1987- 2019 sebanyak 16.645 orang dan terbanyak pada rentang usia 20-49 tahun yaitu sebanyak 12. 411 orang(Direktur Jenderal Pencegahan dan Pengendalian Penyakit, 2019).

Berdasarkan data yang diperoleh dari Pengelola Program Inveksi Menular Seksual (IMS) HIV/AIDS Dinas Kesehatan Kota Ternate sebanyak 77 kelurahan di Kota Ternate, terdapat sekitar $40 \%$ kelurahan yang teridentifikasi HIV. Pada tahun 2018 infeksi Human Immunodeficiency Virus/Acquired Immuno Deficiency Syndrom (HOV/AIDS) mencapai 410 orang. Lima golongan yang paling banyak mengidap virus menular adalah ibu rumah tangga (IRT) berjumlah 72 orang(Adrani, 2019). PNS 59 orang, wiraswasta 57 orang, tidak bekerja 40 orang, dan karyawan swasta 40 orang. Penularan HIV/AIDS paling banyak dari suami, atau dari perilaku hubungan seksual sebelum menikah. Kelurahan Bastiong Karance dan Talangame merupakan salah satu dari 77 kelurahan di Kota Ternate yang memiliki kasus HIV/AIDS yang tinggi. Di kelurahan tersebut merupakan tempat padat penduduk dan mobilisasi social yang tinggi. Kasus HIV/AIDS di Kelurahan Bastiong Karance banyak ditemukan pada ibu rumah tangga. Oleh Karena itu dibutuhkan upaya pencegahan dan penyebaran informasi terkait HIV/AIDS.

Sebagian besar orang yang hidup dengan HIV/AIDS (ODHA) adalah orang dewasa yang berada dalam usia kerja dan hampir separuhnya adalah wanita (Isni, 2016). Anggapan masyarakat bahwa HIV dan AIDS hanya dialami perempuan penjajah seks ternyata tidak benar, karena saat ini perempuan yang tidak melakukan perilaku beresiko telah ada yang terinfeksi HIV dari pasangan tetapnya (suaminya)(Komisi Penanggulan HIV dan AIDS Nasional, 2015; Ramjee \& Daniels, 2013; Silva-Santisteban et al., 2012). Kerentanan perempuan terhadap HIV lebih banyak disebabkan ketimpangan gender yang berakibat pada ketidakmampuan perempuan untuk mengontrol perilaku seksual suami atau pasangan tetapnya dan kurangnya pengetahuan serta akses untuk mendapatkan informasi dan pelayanan pengobatan HIV dan AIDS (Komisi Penanggulan HIV dan AIDS Nasional, 2015). 
Keterlibatan masyarakat dan pemberdayaan merupakan salah satu prinsip penanggulangan HIV dan AIDS. Penguatan sistem komunitas (Community System Strengthening - CSS) dalam penanggulangan AIDS bertujuan untuk mencapai hasil kesehatan yang lebih baik dengan partisipasi aktif populasi terdampak serta organisasi berbasis komunitas dalam melakukan perencanaan, pelaksanaan, monitoring dan evaluasi layanan dan kegiatan yang berkaitan dengan pencegahan, pengobatan, perawatan dan dukungan bagi ODHA. Sejak upaya penanggulangan AIDS dimulai di Indonesia, telah ada pengakuan terhadap peran penting organisasi berbasis komunitas, masyarakat terdampak, populasi kunci, komunitas dan ODHA dalam penanggulangan AIDS di Indonesia. Namun keberlanjutan dukungan terhadap komunitas merupakan tantangan seiring dengan menurunnya dukungan pendanaan internasional(Kementerian Negara Pemberdayaan Perempuan RI, 2008).

Berbagai kebijakan dan program penanggulangan HIV-AIDS telah dilakukan namun, penyebaran HIVAIDS terus berkembang. Untuk itu memerlukan perhatian semua pihak, terutama kalangan perguruan tinggi salah satunya Poltekkes Kemenkes Ternate. Melalui kegiatan Pengabdian masyarakat akan dilakukan program pemberdayaan perempuan sebagai vulnerable group dalam penyebaran HIV/AIDS di Kota Ternate. Adapun tujuan dari kegiatan ini adalah untuk meningkatkan pengetahuan ibu rumah tangga dalam upaya pencegahan penularan HIV/AIDS dengan edukasi ABCD di Kelurahan Bastiong Karance Kota Ternate. Diharapkan dengan adanya kegiatan ini dapat memberikan gambaran terkait dengan HIV/AIDS dan ibu rumah tangga sebagai kelompok rentan dapat memahami bagaimana pencegahan dari penularan HIV/AIDS salah satunya dengan edukasi ABCD serta ibu rumah tangga sebagai kelompok sasaran dapat menjadi komunikator yang baik dalam penyebaran informasi terkait pencegahan HIV/AIDS.

\section{Metode Pengabdian}

Lokasi pengabdian kepada masyarakat dilakukan di Kelurahan Bastiong Karance Kota Ternate dengan sasaran kegiatan adalah Ibu rumah tangga. Kegiatan ini dilakukan dengan menggunakan metode pemberdayaan dengan bentuk kegiatan sosialisasi dan pemberian informasi berbasis gender (ibu rumah tangga) dengan tahapan kegiatan sebagai berikut:

1) Tahap Pertama

Tahap pertama merupakan perencanaan kegiatan yang akan dilakukan. Proses perencanaan meliputi identifikasi kebutuhan, identifikasi potensi dan kelemahan yang ada, menentukan jalan keluar dan kegiatan yang akan dilakukan, dan membuat pengorganisasian kegiatan. Tim pengabdian dan LSM Ronora akan bertindak sebagai fasilitator.

2) Tahap Kedua

Tahap kedua merupakan pelaksanaan kegiatan. Kegiatan dilaksanakan melalui kerjasama dan koordinasi dengan fasilitator kegiatan yaitu LSM Ronora dan ODHA untuk melakukan sosialisasi dan pemberian informasi kepada kelompok rentan (ibu rumah tangga).

3) Tahap Ketiga

Pada tahap ketiga, dilakukan monitoring dan evaluasi kegiatan. Evaluasi kegiatan dilakukan dalam dua bentuk, yang pertama evaluasi selama proses Penyuluhan yaitu evaluasi dilakukan dengan melihat partisipasi dan keaktifan dalam proses tanya jawab selama kegiatan berlangsung dan tahap akhir dapat memaparkan/menjabarkan terkait dengan HIV/AIDS. Kedua, evaluasi pasca penyuluhan penyelesaian materi dan mengamati 
respon dari peserta (ibu rumah tangga). Evaluasi kegiatan dilakukan dengan memberikan posttest kepada peserta penyuluhan untuk mengukur tingkat pengetahuan setelah diberikan penyuluhan. Hasil pre dan posttest kemudian dianalisis mengunakan SPSS dengan uji normalitas dan uji T. Kegiatan ini menjadi bahan evaluasi untuk program/kegiatan kedepannya. Adapun evaluasi kegiatan pengabdian kepada masyarakat dapat dilihat pada tabel 1 berikut ini.

Tabel. 1 Tahapan Evaluasi

\begin{tabular}{|c|l|l|l|}
\hline No & \multicolumn{1}{|c|}{ Jenis Luaran } & \multicolumn{1}{c|}{ Partisipasi Mitra } & \multicolumn{1}{c|}{ Target } \\
\hline 1 & $\begin{array}{l}\text { Dilakukan perencanaan } \\
\text { kegiatan pemberdayaan ibu } \\
\text { rumah tangga sebagai } \\
\text { vulnareble group } \\
\text { penyebarluasan HIV/AIDS }\end{array}$ & $\begin{array}{l}\text { Mitra diharapkan dapat } \\
\text { menarik masyarakat untuk } \\
\text { mengikuti kegiatan yang } \\
\text { akan dilaksanakan }\end{array}$ & $\begin{array}{l}\text { Koordinasi terjalin } \\
\text { dengan baik, } \\
\text { terpenuhinya } \\
\text { kebutuhan- } \\
\text { kebutuhan }\end{array}$ \\
\hline 2 & $\begin{array}{l}\text { Pelaksanaan peningkatan } \\
\text { pengetahuan bagi ibu rumah } \\
\text { tangga melalui sosiaisasi dan } \\
\text { edukasi dalam pencegahan } \\
\text { penularan HIV/AIDS }\end{array}$ & $\begin{array}{l}\text { Mitra memfasilitasi } \\
\text { penyelenggaraan kegiatan }\end{array}$ & $\begin{array}{l}\text { Terlaksananya } \\
\text { kegiatan sosialisasi } \\
\text { dan edukasi pada } \\
\text { ibu rumah tangga } \\
\text { melalui sosiaisasi } \\
\text { dan edukasi sebagai } \\
\text { bentuk pencegahan } \\
\text { penularan } \\
\text { HIV/AIDS }\end{array}$ \\
\hline 3 & $\begin{array}{l}\text { Monitoring dan evaluasi } \\
\text { kegiatan }\end{array}$ & $\begin{array}{l}\text { Mitra memfasilitasi } \\
\text { penyelenggaraan kegiatan }\end{array}$ & $\begin{array}{l}\text { Tolak ukur } \\
\text { keberhasilan } \\
\text { kegiatan yang telah } \\
\text { dilaksanakan }\end{array}$ \\
\hline
\end{tabular}

\section{Hasil Pengabdian dan Pembahasan}

Kegiatan pengabdian kepada masyarakat dilakukan dengan beberapa tahapan dimulai dari survey, pelaksanaan kegiatan dan evaluasi kegiatan. Rangkaian tahapan tersebut dijabarkan sebagai berikut:

1) Survey

Kegiatan pengabdian kepada masyarakat didahului dengan survey pendahuluan. Survey pendahuluan dilakukan serta wawancara dengan pihak Dinas Kesehatan Kota Ternate, Kepala Puskesmas Kalumata, Kepala Kelurahan Bastiong Karance dan kader kesehatan yang berada di wilayah kerja Puskesmas Kalumata. Berdasarkan hasil survey pendahuluan dan wawancara diperoleh informasi bahwa penyebaran dan potensi penderita HIV/AIDS paling banyak di kelurahan Bastiong Karance. Pihak Dinas Kesehatan Kota menyatakan bahwa perlu diberikan sosialisasi terkait HIV/AIDS terutama bagi ibu rumah tangga, mengingat bahwa kerentanan dan angka penderita HIV/AIDS terbanyak pada ibu rumah tangga.

Berdasarkan informasi tersebut dan hasil diskusi yang telah dilakukan maka disepakati untuk melaksanakan kegiatan penyuluhan terkait HIV/AIDS kepada ibu rumah tangga. Sebelum melakukan penyuluhan terlebih dahulu peserta diberikan pretest untuk melihat pengetahuan awal sebelum diberikan penyuluhan. Penyuluhan dihadiri oleh Kepala Puskesmas, Kepala Kelurahan, Kader Kesehatan Bastiong Karance dan Tim 
Pengabdian Masyarakat Poltekkes Kemenkes Ternate. Setelah dilakukan kesepakatan ketua tim peneliti menyusun bahan materi presentasi dan membuat leaflet sebagai penunjang kegiatan penyuluhan yang akan dilakukan. Bahan materi dsusan dalam bentuk power point yang sederhana dengan menggunakan redaksi kalimat yang mudah dipahami. Mengingat bahwa sasaran daripenyuluhan HIV/AIDS adalah ibu rumah tangga.

\section{2) Pelaksanaan Kegiatan}

Kegiatan penyuluhan dilakukan dengan metode ceramah dan demonstrasi. Penyuluhan dengan metode ceramah dilakukan untuk menyampaikan berbagai informasi mengenai pengenalan tentang HIV/AIDS. Selain ceramah dan demonstrasi juga dibagikan leaflet kepada seluruh peserta penyuluhan yang dihadiri oleh 35 ibu rumah tangga. Pada kesempatan yang diberikan disampaikan beberapa hal terkait gambaran umum penyakit HIV/AIDS, gejala, penularan dan pencegahan penularan HIV/AIDS.
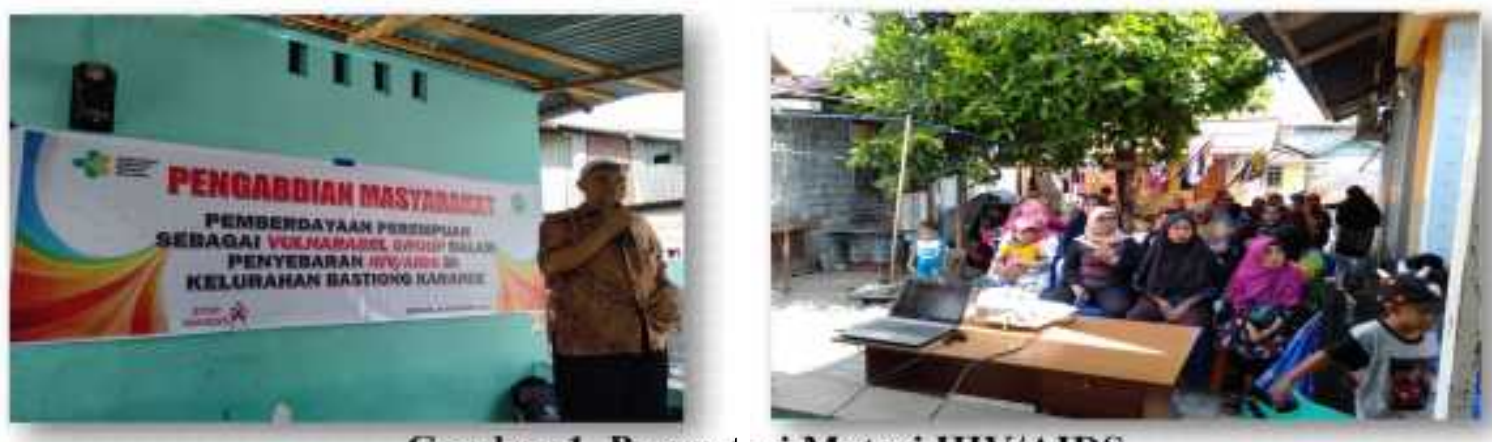

Gambar 1. Presentasi Materi HIV/AIDS

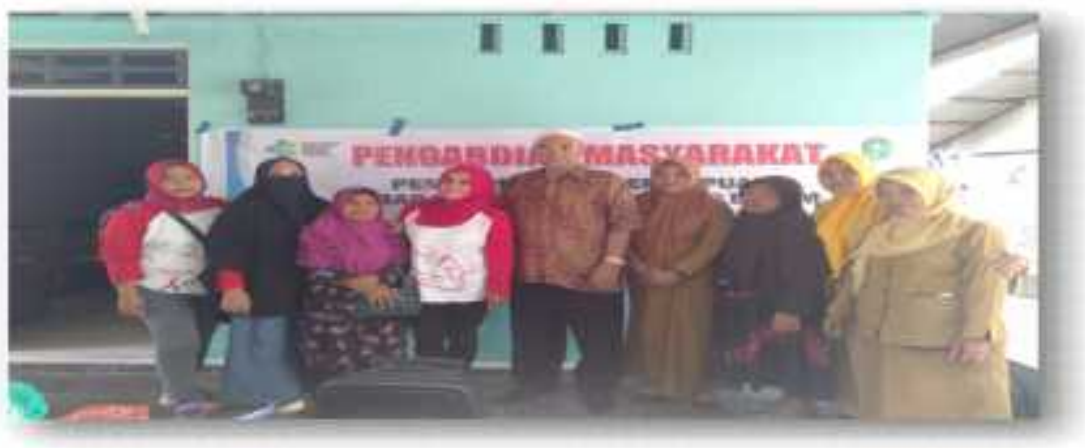

Gambar 2. Peserta Sosialisasi HIV/AIDS

Setelah melakukan penyuluhan diberikan posttest kepada peserta untuk melihat sejauhmana perubahan tingkat pengetahuan sesudah diberikan penyuluhan. Evaluasi kegiatan dilakukan dalam dua bentuk pertama evaluasi selama proses Penyuluhan yaitu evaluasi dilakukan dengan melihatpartisipasi dan keaktifan dalam proses Tanya jawab selama kegiatan berlangsung dan di tahap akhir dapat memaparkan/menjabarkan terkait dengan HIV/AIDS. Kedua, Evaluasi Pasca Penyuluhan Keberhasilan evaluasi ini berdasarkan penyelesaian materi dan mengamati respon dari peserta (ibu rumah tangga). Selama dilakukan penyuluhan peserta sangat antusias untuk mengikuti dan memberikan tanggapan terhadap materi yang disampaikan. 


\section{3) Hasil Evaluasi}

Evaluasi kegiatan penyuluhan dengan melihat hasil pre dan posttest. Berikut hipotesis yang digunakan:

a. Ho : Tidak ada perbedaan rata-rata pengetahuan responden sebelum dan sesudah diberikan penyuluhan

b. Ha: Ada Perbedaan rata-rata antara pengetahuan responden sebelum dan sesudah diberikan penyuluhan

c. Ho ditolak Jika Sig (2 tailed) $<0,005$

d. Ho diterima Jika Sig (2 tailed) $>0,005$

Berdasarkan Tabhasil analisis diketahui bahwa nilai (2 tailed) $>0,005$, maka kesimpulan Ho ditolak, artinya ada perbedaan pengetahuan responden sebelum dan sesudah diberikan penyuluhan. Berikut grafik pengetahuan responden sebelum dan sesudah diberikan penyuluhan.

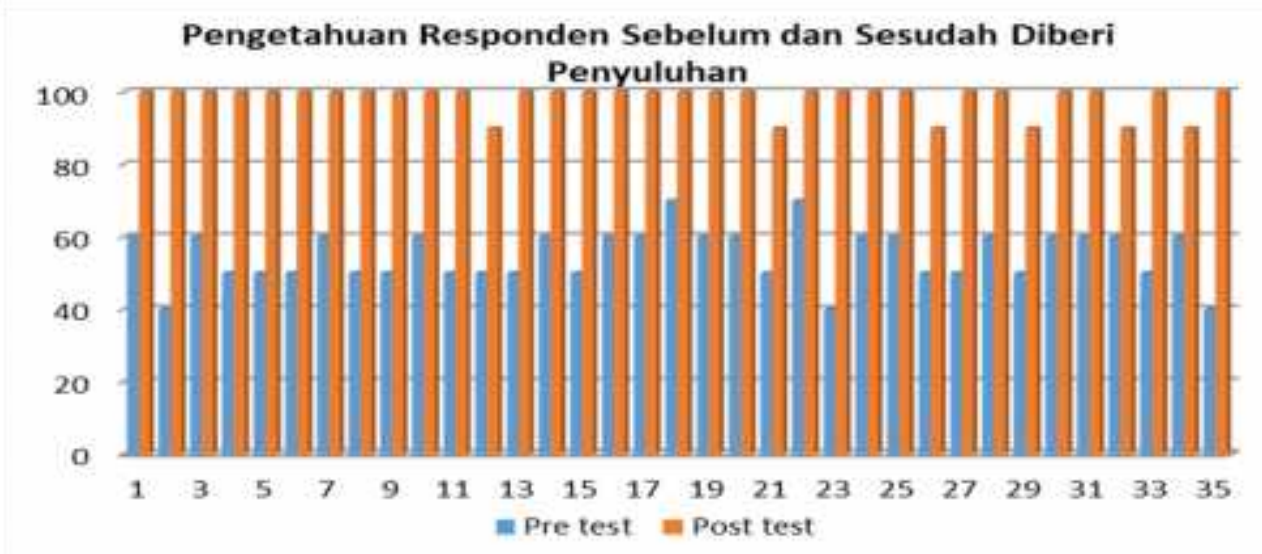

Gambar 3. Grafik Pengetahuan Responden Sebelum dan Sesudah Diberi Penyuluhan

Pada Gambar 3 yang ditampilkan merupakan hasil dari pertanyaan yang diisi oleh peserta sebelum dan sesudah penyuluhan. Pada grafik tersebut dapat dilihat bahwa peserta yang mengikuti penyuluhan sebagian besar masih memiliki pengetahuan yang masih terbatas mengenai penyakit HIV/AIDS. Sebelum penyuluhan rata-rata pengetahuan peserta berada diangka 40 dan paling tinggi diangka 65. Namun setelah diadakan penyuluhan ada peningkatan pengetahuan yang signifikan pada peserta yaitu pengetahuan berada pada angka $95-100$.

\section{Pembahasan}

Penyuluhan adalah penyampaian informasi dari sumber informasi kepada seseorang atau sekelompok orang mengenai berbagai hal yang berkaitan dengan suatu program(Kaddi, 2014). Beberapa metode yang dapat digunakan dalam penyuluhan terdiri dari Metode ceramah, Metode diskusi kelompok, Metode curah pendapat, Metode panel, Metode bermain peran, Metode symposium dan Metode seminar. Metode yang digunakan dalam penyuluhan ini adalah metode ceramah. Metode ceramah dilakukan dengan menerangkan dan menjelaskan suatu ide, pengertian atau pesan secara lisan kepada skelompok sasaran shingga memperoleh informasi tentang kesehatan yang dalam hal ini adalah ibu rumah tangga.

Berdasarkan Tabel 1 diketahui bahwa nilai ( 2 tailed) $>0,005$, maka dapat kesimpulan bahwa Ho ditolak, artinya ada perbedaan pengetahuan responden sebelum dan sesudah diberikan penyuluhan. Keadaan ini dapat menggambarkan bahwa penyuluhan kesehatan merupakan suatu kegiatan yang dapat mempengaruhi perubahan responden meliputi 
pengetahuan. Effendi and Makhfudli (2009) mengatakan bahwa pengetahuan merupakan dari hasil tahu, dan ini terjadi setalah orang melakukan pengindraan terhadap suatu objek tertentu. Penginderaan terjadi melalui panca indera manusia, yakni indera penglihatan, pendengaran, penciuman, rasa dan raba. Sebagian besar pengetahuan manusia diperoleh melalui mata dan telinga seperti poster, majalah, atau sumber informasi yang berbentuk tulisan dan informasi yang berbentuk suara seperti seminar, penyuluhan, atau pembicaraan dari orang lain melalui percakapan seharihari. Pengetahuan kesehatan dapat ditingkatkan dengan cara memberikan edukasi tentang kesehatan melalui penyuluhan atau promosi kesehatan. Penyuluhan kesehatan adalah suatu kegiatan pendidikan yang dilakukan dengan cara menyebarkan pesan, menanamkan keyakinan sehingga masyarakat tidak hanya tahu dan mengerti tetapi juga dapat melakukan suatu anjuran yang ada hubungannya dengan kesehatan.

Media promosi kesehatan merupakan salah satu sarana atau upaya yang dapat digunakan untuk menampilkan pesan atau informasi kesehatan yang ingin disampaikan kepada remaja sehingga dapat meningkatkan pengetahuannya yang akhirnya diharapkan dapat merubah perilakunya kearah positif atau mendukung terhadapa kesehatan. Hal ini sejalan dengan teori yang dikemukakan oleh Syafrudin and Fratidhina (2009) yang menyatakan bahwa penggunaan metode penyuluhan dan media penyuluhan yang tepat dapat meningkatkan efisiensi dan efektifitas dalam pelaksanaan penyuluhan kesehatan di masyarakat. Pada dasarnya penyuluhan kesehatan sebagai bagian dalam promosi kesehatan memang diperlukan sebagai upaya meningkatkan kesadaran dan pengetahuan. Oleh karena itu, tentu diperlukan upaya penyediaan dan penyampaian informasi yang merupakan bidang garapan penyuluhan kesehatan. Makna asli penyuluhan adalah pemberian penerangan dan informasi, maka setelah dilakukan penyuluhan kesehatan seharusnya akan terjadi peningkatan pengetahuan oleh masyarakat. Kegiatan pemberdayaan perempuan yang telah dilakukan di Kelurahan Bastiong Karance diharapkan dapat dilaksanakan di kelurahan lainnya yang bertempat di Kelurahan Talangame. Dengan adanya kegiatan pemberdayaan perempuan ini diupayan agar ibu rumah tangga sebagai kelompok rentan dapat menerapkan ABCD dalam penanggulangan penyakit HIV/AIDS.

\section{Kesimpulan}

Kesimpulan dalam pelaksanaan pengabdian kepada masyarakat yaitu kegiatan penyuluhan terkait HIV/AIDS dapat diterima oleh masyarakat Kelurahan Bastiong Karance, seluruh program dapat dilaksanakan sesuai dengan jadwal yang telah ditentukan dan adanya peningkatan pengetahuan dalam upaya pencegahan penularan HIV/AIDS di Kelurahan Bastiong Karance Kota Ternate.

\section{Saran}

Adapaun saran yang dapat disampaikan berdasarkan hasil kegiatan ini adalah tim pengabdian kepada masyarakat Poltekkes Kemenkes Ternate sebaiknya melaksanakan Penyuluhan terkait HIV/AIDS secara menyeluruh di kelurahan Bastiong mengingat di Kelurahan Bastiong memiliki dua wilayah yaitu Karance dan Talangame yang merupakan wilayah rentan dengan HIV/AIDS.

\section{Daftar Pustaka}

Adrani, N. (2019). Kasus HIV/AIDS di Malut dan Kota Ternate di Tahun 2018 Meningkat. Radio Republik Indonesia. 
Direktur Jenderal Pencegahan dan Pengendalian Penyakit. (2019). Laporan Situasi Perkembangan HIV/AIDS dan PIMS di Indonesia Januari-Maret 2019. Jakarta: Direktur Jenderal Pencegahan dan Pengendalian Penyakit.

Dom, R. M., Kareem, S. A., Abidin, B., Kamaruzaman, A., \& Kajindran, A. (2009). The Prediction of AIDS Survival: a Data Mining Approach. Paper presented at the Proceedings of the 2nd WSEAS International Conference on Multivariate Analysis and its Application in Science and Engineering.

Eda, N., Widjanarko, B., \& Widagdo, L. (2012). Niat Penggunaan Kondom pada Komunitas Wariadi Kota Ternate. Jurnal Promosi Kesehatan Indonesia, 7(2), 174-183.

Effendi, F., \& Makhfudli. (2009). Keperawatan Kesehatan Komunitas. Jakarta: Salemba Medika.

Fitrianingsih, R., Dewi, Y. I., \& Woferst, R. (2018). Faktor-Faktor yang mempengaruhi Perilaku Pencegahan HIV/AIDS pada Ibu Rumah Tangga. Jurnal Ners Indonesia, 9(1), 59-71.

Isni, K. (2016). Dukungan Keluarga, Dukungan Petugas Kesehatan, dan Perilaku Ibu HIV dalam Pencegahan Penularan HIV/AIDS Ke Bayi. Kesehatan Masyarakat, 11(2), 96104.

Kaddi, S. M. (2014). Strategi Penyuluhan Kesehatan Masyarakat dalam Menanggulangi Bahaya Narkoba di Kabupaten Bone. Jurnal Academica Fisip Untad, 6(1), 11781185.

Kaida, A., Carter, A., de Pokomandy, A., Patterson, S., Proulx-Boucher, K., Nohpal, A., . . . Thomas-Pavanel, J. (2015). Sexual Inactivity and Sexual Satisfaction Among Women Living With HIV in Canada in The Context of Growing Social, Legal and Public Health Surveillance. Journal of the International AIDS Society, 18, 20284.

Kementerian Negara Pemberdayaan Perempuan RI. (2008). Pemberdayaan Perempuan Dalam [Pencegahan Penyebaran HIV/AIDS. Jakarta Kementerian Negara Pemberdayaan Perempuan RI.

Komisi Penanggulan HIV dan AIDS Nasional. (2015). Strategi dan Rencana Aksi Nasional 2015-2019. Jakarta: Komisi Penanggulan HIV dan AIDS Nasional.

Ramjee, G., \& Daniels, B. (2013). Women and HIV in sub-Saharan Africa. AIDS research and therapy, $10(1), 30$.

Samanta, G. P. (2010). Analysis of a Nonautonomous HIV/AIDS Epidemic Model With Distributed Time Delay. Mathematical Modelling and Analysis, 15(3), 327-347.

Santoso, E. B., \& Akbar, H. (2018). Penyerapan Pengetahuan tentang HIV/AIDS pada Siswa di SMK Endang Darma Ayu Sebelum dan Sesudah Penyuluhan. Gema Wiralodra, 9(2), 106-114.

Silva-Santisteban, A., Raymond, H. F., Salazar, X., Villayzan, J., Leon, S., McFarland, W., \& Caceres, C. F. (2012). Understanding the HIV/AIDS Epidemic in Transgender Women of Lima, Peru: Results From a Sero-Epidemiologic Study Using Respondent Driven Sampling. AIDS and Behavior, 16(4), 872-881.

Syafrudin, \& Fratidhina. (2009). Promosi Kesehatan untuk Mahasiswa Kebidanan. Jakarta: Trans Info Media.

Zeth, A. H. M., Asdie, A. H., Mukti, A. G., \& Mansoden, J. (2010). Perilaku dan Risiko Penyakit HIV-AIDS di Masyarakat Papua Studi Pengembangan Model Lokal Kebijakan HIV-AIDS. Jurnal Manajemen Pelayanan Kesehatan, 13(4), 206-219. 